\title{
Nitrate facilitates cadmium uptake, transport and accumulation in the hyperaccumulator Sedum plumbizincicola
}

\author{
Pengjie Hu • Yong-Gen Yin • Satoru Ishikawa • \\ Nobuo Suzui • Naoki Kawachi • Shu Fujimaki • \\ Masato Igura - Cheng Yuan - Jiexue Huang - Zhu Li • \\ Tomoyuki Makino • Yongming Luo • Peter Christie • \\ Longhua Wu
}

Received: 6 February 2013 /Accepted: 25 March 2013 /Published online: 16 April 2013

(C) Springer-Verlag Berlin Heidelberg 2013

\begin{abstract}
The aims of this study are to investigate whether and how the nitrogen form (nitrate $\left(\mathrm{NO}_{3}{ }^{-}\right)$versus ammonium $\left(\mathrm{NH}_{4}{ }^{+}\right)$) influences cadmium (Cd) uptake and translocation and subsequent $\mathrm{Cd}$ phytoextraction by the hyperaccumulator species Sedum plumbizincicola. Plants were grown hydroponically with $\mathrm{N}$ supplied as either $\mathrm{NO}_{3}^{-}$or $\mathrm{NH}_{4}^{+}$. Short-term $(36 \mathrm{~h}) \mathrm{Cd}$ uptake and translocation were determined innovatively and quantitatively using a positron-emitting ${ }^{107} \mathrm{Cd}$
\end{abstract}

Responsible editor: Stuart Simpson

P. J. Hu and Y.-G. Yin contributed equally to this work.

Electronic supplementary material The online version of this article (doi:10.1007/s11356-013-1680-3) contains supplementary material, which is available to authorized users.

P. $\mathrm{Hu} \cdot$ C. Yuan $\cdot$ J. Huang $\cdot$ Z. Li $\cdot$ L. Wu $(\triangle)$

Key Laboratory of Soil Environment and Pollution Remediation, Institute of Soil Science, Chinese Academy of Sciences,

Nanjing 210008, China

e-mail:1hwu@issas.ac.cn

Y.-G. Yin • N. Suzui $\cdot$ N. Kawachi $\cdot$ S. Fujimaki

Japan Atomic Energy Agency, Gunma 370-1292, Japan

S. Ishikawa $\cdot$ M. Igura $\cdot$ T. Makino

National Institute for Agro-Environmental Sciences,

Ibaraki 305-8604, Japan

Y. Luo

Yantai Institute of Coastal Zone Research, Chinese Academy

of Sciences, Yantai 264003, China

P. Christie

Agri-Environment Branch, Agri-Food and Biosciences Institute,

Newforge Lane,

Belfast BT9 5PX, UK tracer and positron-emitting tracer imaging system. The results show that the rates of $\mathrm{Cd}$ uptake by roots and transport to the shoots in the $\mathrm{NO}_{3}{ }^{-}$treatment were more rapid than in the $\mathrm{NH}_{4}^{+}$treatment. After uptake for $36 \mathrm{~h}, 5.6(0.056 \mu \mathrm{M})$ and $29.0 \%(0.290 \mu \mathrm{M})$ of total $\mathrm{Cd}$ in the solution was nonabsorbable in the $\mathrm{NO}_{3}{ }^{-}$and $\mathrm{NH}_{4}{ }^{+}$treatments, respectively. The local velocity of $\mathrm{Cd}$ transport was approximately 1.5 -fold higher in roots $\left(3.30 \mathrm{~cm} \mathrm{~h}^{-1}\right)$ and 3.7-fold higher in shoots $\left(10.10 \mathrm{~cm} \mathrm{~h}^{-1}\right)$ of $\mathrm{NO}_{3}^{-}$- than $\mathrm{NH}_{4}{ }^{+}$-fed plants. Autoradiographic analysis of ${ }^{109} \mathrm{Cd}$ reveals that $\mathrm{NO}_{3}{ }^{-}$nutrition enhanced $\mathrm{Cd}$ transportation from the main stem to branches and young leaves. Moreover, $\mathrm{NO}_{3}{ }^{-}$treatment increased $\mathrm{Cd}$, $\mathrm{Ca}$ and $\mathrm{K}$ concentrations but inhibited $\mathrm{Fe}$ and $\mathrm{P}$ in the xylem sap. In a 21-day hydroponic culture, shoot biomass and $\mathrm{Cd}$ concentration were 1.51 and 2.63 times higher in $\mathrm{NO}_{3}{ }^{-}$- than in $\mathrm{NH}_{4}{ }^{+}$-fed plants. We conclude that compared with $\mathrm{NH}_{4}{ }^{+}$, $\mathrm{NO}_{3}{ }^{-}$promoted the major steps in the transport route followed by $\mathrm{Cd}$ from solution to shoots in S. plumbizincicola, namely its uptake by roots, xylem loading, root-to-shoot translocation in the xylem and uploading to the leaves. S. plumbizincicola prefers $\mathrm{NO}_{3}{ }^{-}$nutrition to $\mathrm{NH}_{4}{ }^{+}$for $\mathrm{Cd}$ phytoextraction.

Keywords Ammonium · Cadmium · Nitrate · Positronemitting tracer imaging system (PETIS) $\cdot$ Sedum plumbizincicola $\cdot$ Transport $\cdot$ Uptake $\cdot$ Xylem sap

\section{Introduction}

Cadmium (Cd) is one of the most hazardous and ubiquitous inorganic contaminants in soils and waters. Dietary intake of food from crops grown in Cd-contaminated soils poses risks 
to human health. Among the various remediation techniques available, phytoextraction, the use of metal hyperaccumulator plants to remove pollutants from soils, is considered to be a cost-efficient and environmentally friendly method, although it still faces many challenges (McGrath et al. 2006). The mechanisms of hypertolerance and hyperaccumulation by plants have been studied extensively in recent years. There are various physiological steps in the transport route taken by $\mathrm{Cd}$ in hyperaccumulators from the rhizosphere to the shoots which are of great importance for phytoextraction, such as root uptake, xylem loading, root-to-shoot translocation, unloading in the shoots and sequestration in the shoots. The rate of $\mathrm{Cd}$ transportation at each step may show high dependency on the activities of transporter proteins located in the plasma membrane or tonoplast membrane. Cd uptake in hyperaccumulators appeared to occur partly through other cation transporters such as iron (Fe) (Lombi et al. 2002) or zinc ( $\mathrm{Zn}$ ) (Zhao et al. 2006) or calcium (Ca) channels (Lu et al. 2008). The root-to-shoot translocation of Cd may be affected by the activity of transporter proteins such as HMA4 contributing to xylem loading and unloading (Papoyan and Kochian 2004; Courbot et al. 2007). Cd hypertolerance is achieved mainly through vacuolar sequestration and complexation with ligands (Kupper et al. 2004; Ma et al. 2005; Ueno et al. 2005).

Nitrogen $(\mathrm{N})$ is an essential macronutrient for the biosynthesis of amino acids, proteins, and enzymes in plants. Nitrate $\left(\mathrm{NO}_{3}{ }^{-}\right)$and ammonium $\left(\mathrm{NH}_{4}{ }^{+}\right)$are the main inorganic $\mathrm{N}$ sources for plants in most agricultural systems. Since N accounts for $80 \%$ of the total nutrients taken up by roots, the chemical form in which it is absorbed strongly influences the cellular charge balance. Physiologically, the uptake of $\mathrm{NO}_{3}{ }^{-}$ and $\mathrm{NH}_{4}{ }^{+}$induces a net release of $\mathrm{OH}^{-} / \mathrm{HCO}_{3}{ }^{-}$and $\mathrm{H}^{+}$ions, respectively. Therefore, when $\mathrm{NH}_{4}^{+}$is supplied the decrease in rhizosphere $\mathrm{pH}$ results in an increase in metal bioavailability and consequently an increase in metal accumulation by the plant (Zaccheo et al. 2006). However, it was reported that $\mathrm{NO}_{3}{ }^{-}$transport across the plasma membrane results in the membrane potential being temporarily depolarised but it is then hyperpolarised (McClure et al. 1990; Miller et al. 2001) and this may enhance the membrane transport of cations. In contrast, uptake of $\mathrm{NH}_{4}{ }^{+}$depolarises the membrane potential and thus inhibits cation uptake (Crawford and Glass 1998). Some studies have reported that fertilisation with $\mathrm{NO}_{3}{ }^{-}$ (but not $\mathrm{NH}_{4}^{+}$) increases shoot $\mathrm{Cd}$ and $\mathrm{Zn}$ content and shoot biomass of Noccaea caerulescens (formerly Thlaspi caerulescens) and thus enhances $\mathrm{Cd}$ and $\mathrm{Zn}$ hyperaccumulation (Schwartz et al. 2003; Monsant et al. 2008; Xie et al. 2009). Similar enhancement of Cd accumulation has also been found in other plant species such as camomile (Kovacik et al. 2011) and tomato (Luo et al. 2012).

In general, radioisotope tracers such as ${ }^{109} \mathrm{Cd}$ are useful tools for analysing $\mathrm{Cd}$ uptake kinetics based on temporal changes in the amount of a substance in the plant body (Zhao et al. 2002; Lu et al. 2008). ${ }^{109} \mathrm{Cd}$ has also been widely used to visualise $\mathrm{Cd}$ distribution within plant tissues by autoradiography (Cosio et al. 2005). However, only the static distribution of $\mathrm{Cd}$ at a given moment can be obtained by autoradiography. In recent years, the positron-emitting tracer imaging system (PETIS) has been employed to study the uptake and translocation of metals using the positronemitting tracers ${ }^{52} \mathrm{Mn}$ (Tsukamoto et al. 2006), ${ }^{62} \mathrm{Zn}$ (Suzuki et al. 2008), ${ }^{52} \mathrm{Fe}$ (Tsukamoto et al. 2009) and ${ }^{107} \mathrm{Cd}$ (Fujimaki et al. 2010) in intact living plants. This system enables monitoring of the real-time movement of the tracer in living plants as a video, and also quantitative analysis of the movement of substances by freely selecting a region of interest (ROI) on the image data obtained. Recently, a realtime imaging system for $\mathrm{Cd}$ using positron-emitting ${ }^{107} \mathrm{Cd}$ tracer and PETIS was established (Fujimaki et al. 2010). Ishikawa et al. (2011) improved the design of the root box and realised direct observation of $\mathrm{Cd}$ uptake by the roots in solution culture, and characterised clearly the differences in $\mathrm{Cd}$ dynamics from the culture solution to the grains between high- and low-Cd accumulating rice cultivars. So far, there has been no application of PETIS to investigate Cd uptake by any hyperaccumulator species.

Sedum plumbizincicola, a species in the family Crassulaceae (Wu et al. 2006, 2013a), has been reported to be a $\mathrm{Cd}$ hyperaccumulator exhibiting fast growth, large biomass, asexual reproduction and perennial habit (Wu et al. 2007, 2008) and showing remarkable potential in the phytoextraction of $\mathrm{Cd}$ from polluted soils (Jiang et al. 2010; Liu et al. 2011; Wu et al. 2013b). In mining areas, $\mathrm{Cd}$ concentrations in the shoots reached $241 \mathrm{mg} \mathrm{kg}^{-1}$ (unpublished data). In a pot experiment, the $\mathrm{Cd}$ concentrations in stems and leaves reached 424 and $285 \mathrm{mg} \mathrm{kg}^{-1}$ when soil $\mathrm{Cd}$ was $15.3 \mathrm{mg} \mathrm{kg}^{-1}$ (Wu et al. 2007). In a field plot experiment, the shoot dry biomass reached $12 \mathrm{t} \mathrm{ha}^{-1}$ and $\mathrm{Cd}$ uptake reached $0.65 \mathrm{~kg} \mathrm{ha}^{-1}$ when the plants were grown in soils contaminated with $3 \mathrm{mg} \mathrm{kg}^{-1} \mathrm{Cd}$ (Liu et al. 2009, 2011). There is much interest in increasing $\mathrm{Cd}$ extraction capacity and biomass yields of $S$. plumbizincicola to increase remediation efficiency ( $\mathrm{Wu}$ et al. 2012). It is not known whether and how the form of $\mathrm{N}$ influences the growth, $\mathrm{Cd}$ uptake and translocation by this species. In soil conditions, $\mathrm{NH}_{4}{ }^{+}$is readily oxidised to nitrite and $\mathrm{NO}_{3}^{-}$by the soil-nitrifying bacteria and the soil $\mathrm{pH}$ is influenced by biological processes (Sarathchandra 1978; Zaccheo et al. 2006). The effects of $\mathrm{N}$ form can be compared in a solution culture experiment in which the solution $\mathrm{pH}$ and $\mathrm{N}$ form are maintained constant. Thus, in the present study the effects of $\mathrm{N}$ form on plant growth, $\mathrm{Cd}$ uptake and translocation in $S$. plumbizincicola were investigated 
hydroponically to help enhance phytoremediation efficiency. Moreover, real-time imaging and quantitative analysis of $\mathrm{Cd}$ movement in living plants were conducted using ${ }^{107} \mathrm{Cd}$ tracer and PETIS.

\section{Materials and methods}

Plant materials and culture

Shoots of S. plumbizincicola were collected from an old lead/zinc mine area in the suburbs of Hangzhou city, Zhejiang province, east China. Shoots were cultured in Hoagland solution which was aerated continuously and replaced once a week. After 2-4 weeks, healthy plants of uniform size were selected for the subsequent experiments.

At the start of the experiments seedlings were cultured in fresh nutrient solution containing (in micromolars) 50 $\mathrm{KH}_{2} \mathrm{PO}_{4}, 600 \mathrm{~K}_{2} \mathrm{SO}_{4}, 200 \mathrm{MgSO}_{4}, 100 \mathrm{CaCl}_{2}, 10$ FeEDDHA, $5 \mathrm{ZnSO}_{4}, 5 \mathrm{H}_{3} \mathrm{BO}_{3}, 1 \mathrm{MnSO}_{4}, 0.2 \mathrm{CuSO}_{4}$, $0.03 \mathrm{Na}_{2} \mathrm{MoO}_{4}$ and 1,000 2-( $N$-morpholino)ethanesulphonic acid (MES). Two $\mathrm{N}$-source treatments, i.e. $1 \mathrm{mM} \mathrm{NO}_{3}{ }^{-}$and $1 \mathrm{mM} \mathrm{NH}_{4}{ }^{+}$, were supplied as $0.5 \mathrm{mM}$ $\mathrm{Ca}\left(\mathrm{NO}_{3}\right)_{2}$ and $0.5 \mathrm{mM}\left(\mathrm{NH}_{4}\right)_{2} \mathrm{SO}_{4}$, respectively. To provide the same concentration of $\mathrm{Ca}(0.6 \mathrm{mM}), 0.5 \mathrm{mM} \mathrm{CaCl}_{2}$ was supplied in the $\mathrm{NH}_{4}{ }^{+}$treatment. Cd treatments of 1 or $30 \mu \mathrm{M}$ were used depending on the experiments described below. The solution $\mathrm{pH}$ was adjusted to 5.9 with $10 \mathrm{mM}$ Tris. The solution culture experiments were conducted in a controlled environment greenhouse with day/night temperatures of $30 / 25{ }^{\circ} \mathrm{C}$, a relative humidity of $70 \%$ and natural sunlight without supplementary illumination.

\section{Experimental design}

\section{Experiment 1: PETIS analysis}

In this experiment, each seedling was acclimatised in 0.7-L fresh solution containing $1 \mathrm{mM} \mathrm{NO}_{3}^{-}$or $1 \mathrm{mM} \mathrm{NH}_{4}^{+}$for 3 days before the start of the ${ }^{107} \mathrm{Cd}$ supplementation experiment.

\section{Experiment 2: xylem sap analysis}

For xylem sap analysis each treatment had four replicate pots and each pot contained 0.7-L solution and 1 plant. Seedlings were pre-treated with $1 \mathrm{mM} \mathrm{NO}{ }_{3}^{-}$or $\mathrm{NH}_{4}{ }^{+}$for 3 days. Then 1 or $30 \mu \mathrm{M} \mathrm{Cd}$ (supplied as $\mathrm{CdSO}_{4}$ ) was added. Xylem sap collection started $2 \mathrm{~h}$ after $\mathrm{Cd}$ addition according to the methods of Uraguchi et al. (2009). Shoots were cut $3 \mathrm{~cm}$ above the shoot base with fresh razor blades. The shoot incision was quickly washed with distilled water and dried with absorbent paper to remove broken cells from the sap. The shoot stumps were covered with $1.5-\mathrm{mL}$ plastic vials containing a small piece of cotton. Xylem sap (50 $100 \mu \mathrm{L} /$ plant) absorbed in the cotton was collected by centrifuging at 3,000 rpm for $30 \mathrm{~s}$. Elemental concentrations in the xylem sap were determined by ICP-AES (VISTAPRO, Varian, Palo Alto, CA).

\section{Experiment 3: long-term solution culture}

In long-term solution culture seedlings treated with one of the two $\mathrm{N}$ forms were supplied with $30 \mu \mathrm{M} \mathrm{CdSO}{ }_{4}$. Each treatment had four replicate pots, and each pot contained $1 \mathrm{~L}$ solution and two plants. The solution was aerated continuously and renewed every 3 days. Plants were harvested after 6 and 21 days of $\mathrm{N}$ and $\mathrm{Cd}$ treatment. Shoots and roots were quickly rinsed with deionised water. Plants were oven-dried at $80{ }^{\circ} \mathrm{C}$ and were digested with $\mathrm{HNO}_{3}-\mathrm{HClO}_{4}(3: 2, v / v)$. Elemental concentrations in the digests were determined using a flame atomic absorption spectrophotometer (Varian SpectrAA 220 FS, Varian, Palo Alto, CA).

\section{${ }^{107} \mathrm{Cd}$ tracer and PETIS imaging}

The PETIS imaging experiments were conducted following the methods of Fujimaki et al. (2010) and Ishikawa et al. (2011) with some modifications. ${ }^{107} \mathrm{Cd}$ isotope was produced by bombarding a silver foil for $48 \mathrm{~min}$ with a $17-\mathrm{MeV}$ energy proton beam at a current of $2 \mu \mathrm{A}$ delivered from a cyclotron at the Takasaki Ion Accelerator Facility for Advanced Radiation Application at the Japanese Atomic Energy Agency. The irradiated target was dissolved in concentrated nitric acid and the ${ }^{107} \mathrm{Cd}$ was purified by an $\mathrm{AgCl}_{2}$ precipitation reaction after the addition of $2 \mathrm{M} \mathrm{HCl}$. Finally, $22.0 \mathrm{MBq}$ of ${ }^{107} \mathrm{Cd}$ was fed to each test plant.

Seedlings pre-treated with the different $\mathrm{N}$ forms were transferred into $50-\mathrm{mL}$ syringe tubes containing the same solution. Before the imaging experiment, the solution was replaced with fresh solution containing $1 \mathrm{mM} \mathrm{NO}_{3}^{-}$or $\mathrm{NH}_{4}{ }^{+}$. Purified ${ }^{107} \mathrm{Cd}$ and nonradioactive $\mathrm{Cd}$ at a total concentration of $1 \mu \mathrm{M}$ were simultaneously injected into the tube. The solution was stirred continuously with gentle aeration in order to maintain a uniform composition. The surface level of the solution in the tube was continuously maintained by supplying fresh solution (without $\mathrm{Cd}$ ) with an automatic solution supply system. Simultaneously, the rate of water uptake by the plants was continuously monitored by weight. Two opposing detector pairs of the PETIS apparatus (a modified PPIS-4800; Hamamatsu Photonics, Hamamatsu, Japan) were used to image ${ }^{107} \mathrm{Cd}$ tracer in solution and plants which were placed in the mid-plane between the two detectors. A positron emitted from a tracer immediately undergoes annihilation by collision with an electron of an 
adjacent atom in the plant tissue. A pair of annihilation $\gamma$ rays emitted from the decaying positron was detected by the pair of detectors at the same moment. The emission point was then determined as the midpoint of the two incident points. Repeated determinations of the emission points reconstructed a static image of the tracer distribution. One frame, which is the unit of time required to obtain one static image of sufficient quality, was set to $5 \mathrm{~min}$ in this study. Consequently, 432 frames were collected over $36 \mathrm{~h}$ to yield serial time-course imaging. The typical size of the field of view in the detector head was $12 \mathrm{~cm}$ in width and $19 \mathrm{~cm}$ in height and the spatial resolution was approximately $2 \mathrm{~mm}$. All PETIS experiments were conducted in a growth chamber at $25{ }^{\circ} \mathrm{C}$ and $70 \%$ humidity with continuous light at a density of $400 \mu \mathrm{mol} \mathrm{m} \mathrm{m}^{-2}$.

\section{Qualitative and quantitative analyses of PETIS data}

The dataset obtained from the PETIS apparatus was transferred to a personal computer for analysis using NIH Image J $1.45 \mathrm{~s}$ software to determine $\mathrm{Cd}$ dynamics in the solution and plant tissue both qualitatively and quantitatively. Time courses of the radioactivity of ${ }^{107} \mathrm{Cd}$ over time within each ROI were generated through manual selection of ROIs on the image data. A time-course curve of $\mathrm{Cd}$ accumulation within the ROI indicated the amounts of total $\mathrm{Cd}$ consisting of the sums of radioactive and nonradioactive $\mathrm{Cd}$. Data plotting and fitting analysis of the time-activity curves were performed using Gnuplot version 4.2 software (http://www.gnuplot.info/).

\section{Autoradiography}

Test plants were dissected and placed on imaging plates (Fujifilm, Tokyo, Japan) in cassettes after the PETIS imaging and sufficient decay of ${ }^{107} \mathrm{Cd}$. After several days of exposure the imaging plates were scanned using a bioimaging analyser (Typhoon FLA 7000, GE Healthcare, Tokyo, Japan) to obtain the autoradiographic images of ${ }^{109} \mathrm{Cd}$ in the plant bodies. ${ }^{109} \mathrm{Cd}$, with a longer half-life (461 days) than ${ }^{107} \mathrm{Cd}(6.5 \mathrm{~h})$, was also produced at a minor ratio (approximately $1 / 3,000$ ) in the production process of ${ }^{107} \mathrm{Cd}$. This was absorbed by the plants during the PETIS experiments but not detected by the PETIS apparatus because it is not a positron emitter.

\section{Statistics}

All statistical analysis was conducted with SPSS 16.0 for Windows (SPSS Inc., Chicago, IL). Mean values were compared by independent-sample $t$ test or one-way ANOVA followed by Fisher's least significant difference (LSD) test at $P<0.05$.

\section{Results}

Real time ${ }^{107} \mathrm{Cd}$ uptake

Real-time ${ }^{107} \mathrm{Cd}$ uptake and transport by S. plumbizincicola fed with equal concentrations of cations (e.g. $\mathrm{Ca}^{2+}, \mathrm{K}^{+}$and $\left.\mathrm{Mg}^{2+}\right)$ but different $\mathrm{N}$ sources $\left(\mathrm{NO}_{3}{ }^{-}\right.$vs. $\left.\mathrm{NH}_{4}^{+}\right)$was imaged using PETIS. Plants were supplied with $1 \mu \mathrm{M} \mathrm{Cd}(\mathrm{Cd}$ amount was around $45 \mathrm{nmol}$ ) including radioactive ${ }^{107} \mathrm{Cd}$ and subjected to PETIS for $36 \mathrm{~h}$. Figure 1 and Supplementary video $\mathrm{S} 1$ show representative results of PETIS imaging of $\mathrm{Cd}$ uptake and transport. It was clear that in both $\mathrm{N}$ treatments, $\mathrm{Cd}$ was accumulated by the roots immediately after the Cd was supplied and the Cd intensity in the solution decreased simultaneously. Cd appeared in the shoots after around $1 \mathrm{~h}$. However, the decreasing rates of $\mathrm{Cd}$ concentration in the solution and $\mathrm{Cd}$ uptake by the roots and transport into the shoots were faster in the $\mathrm{NO}_{3}{ }^{-}$treatment than in the $\mathrm{NH}_{4}^{+}$treatment.

Qualitative and quantitative analyses of PETIS data of $\mathrm{Cd}$ dynamics were conducted. Time courses of the radioactivity of ${ }^{107} \mathrm{Cd}$ over time within each ROI were generated through manual selection of ROI on the image data. Representative curves of $\mathrm{Cd}$ dynamics in the solution, $\mathrm{Cd}$ uptake into the roots and movement into the shoots are shown in Figs. 2 and 3. Because the volume of the solution was automatically maintained by supplying a fresh solution without $\mathrm{Cd}$ during the experiment, only absorption by the roots would have decreased the amount of $\mathrm{Cd}$ in the culture solution. Therefore, the curve of $\mathrm{Cd}$ dynamics in the solution directly reflected root absorption (Fig. 2b). It was clear that the $\mathrm{Cd}$ concentration in the solution (ROI A and B) decreased rapidly at the beginning and levelled off at about $18 \mathrm{~h}$ in both $\mathrm{N}$ treatments. However, the rate of decrease in $\mathrm{Cd}$ in the $\mathrm{NO}_{3}{ }^{-}$treatment was faster than that in the $\mathrm{NH}_{4}{ }^{+}$treatment. After $36 \mathrm{~h}$ of uptake, $5.6(0.056 \mu \mathrm{M})$ and $29.0 \%$ $(0.290 \mu \mathrm{M})$ of the total $\mathrm{Cd}$ added in the solution remained non-absorbable in $\mathrm{NO}_{3}{ }^{-}$and $\mathrm{NH}_{4}{ }^{+}$treatments, respectively.

To pursue this model, it was assumed that the Cd absorption, which is likely mediated by transporters, follows Michaelis-Menten kinetics in which the reaction rate is approximately proportional to the concentration of the substance in the range below the $K_{\mathrm{m}}$ value. Thus, the curve of $\mathrm{Cd}$ dynamics in solution from 0.5 to $18 \mathrm{~h}$ (Fig. 2b) was fitted by the following equation (Fujimaki et al. 2010):

$c_{\mathrm{ct}}(t)=c_{0} e^{-\mathrm{kt}}+c_{u}$

Where $c_{\mathrm{ct}}(t)$ denotes total Cd level (in micormolars) at time $t(\mathrm{~h}) ; c_{0}$ denotes the initial absorbable Cd level (in micromolars); $k$ denotes the coefficient of the proportionality between the absorption rate and the concentration of $\mathrm{Cd}$ in solution (in hours); and $c_{u}$ denotes the non-absorbable $\mathrm{Cd}$ 
Fig. 1 Serial images of ${ }^{107} \mathrm{Cd}$ movements in S. plumbizincicola fed with $\mathrm{NO}_{3}{ }^{-}$or $\mathrm{NH}_{4}{ }^{+}$ (a)

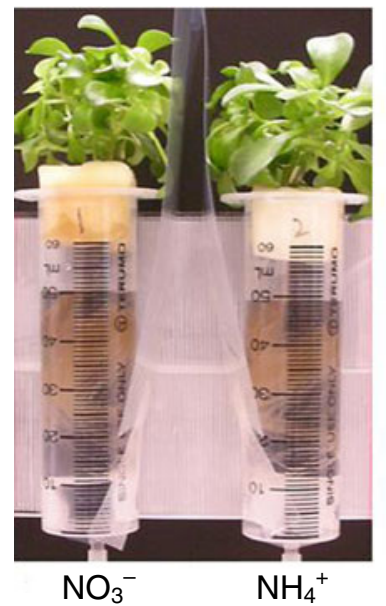

(b)

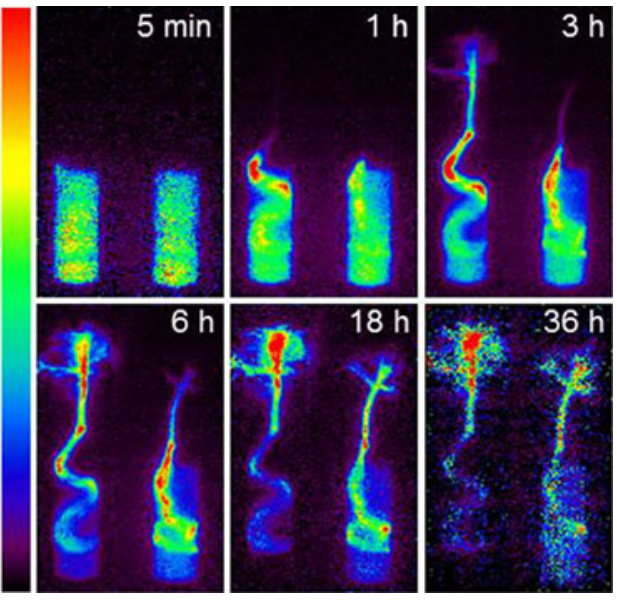

level (in micromolars). The parameters that provided the best fit (Fig. 2b) in the $\mathrm{NO}_{3}{ }^{-}$treatment were estimated to be $c_{0}=0.450 \mu \mathrm{M}, c_{u}=0.089 \mu \mathrm{M}$ and $k=0.505 \mathrm{~h}^{-1}$. By comparison, the parameters in the $\mathrm{NH}_{4}{ }^{+}$treatment were estimated to be $c_{0}=0.414 \mu \mathrm{M}, c_{u}=0.306 \mu \mathrm{M}$ and $k=0.487 \mathrm{~h}^{-1}$. Nevertheless, it was observed that the Cd curve in solution within the first $0.5 \mathrm{~h}$ was complex and decreased faster than the first order reaction kinetics, especially in the $\mathrm{NO}_{3}{ }^{-}$ treatment (Fig. 2b).

Cd transport in the plants

Figure $2 \mathrm{~b}$, d shows the time courses of the amounts of $\mathrm{Cd}$ in whole plant roots and shoots. In roots of both $\mathrm{NO}_{3}{ }^{-}$and $\mathrm{NH}_{4}{ }^{+}$treatments, $\mathrm{Cd}$ accumulation by the roots was observed just after the ${ }^{107} \mathrm{Cd}$ was supplied (Fig. 2b). In the $\mathrm{NO}_{3}{ }^{-}$ treatment, the amount of $\mathrm{Cd}$ in the roots increased more rapidly over time than in the $\mathrm{NH}_{4}{ }^{+}$treatment. The total amount of $\mathrm{Cd}$ in the roots of the $\mathrm{NO}_{3}{ }^{-}$treatment reached a peak of $15.7 \mathrm{nmol}$ at $1.4 \mathrm{~h}$ and then decreased rapidly. The total amount of $\mathrm{Cd}$ in the roots of the $\mathrm{NH}_{4}{ }^{+}$treatment increased slowly and reached a plateau of approximately $14.1 \mathrm{nmol}$ from approximately 5.0 to $7.5 \mathrm{~h}$ and then decreased slowly. The time-course curves of $\mathrm{Cd}$ in shoots showed opposite trends to solution values (Fig. $2 \mathrm{~d}$ ). $\mathrm{Cd}$ in the shoots of the $\mathrm{NO}_{3}{ }^{-}$treatment increased more rapidly and reached a plateau of approximately $31.2 \mathrm{nmol}$ at $21 \mathrm{~h}$ after feeding, while $\mathrm{Cd}$ in the shoots of the $\mathrm{NH}_{4}{ }^{+}$treatment increased slowly and reached a plateau of approximately $16.4 \mathrm{nmol}$ at $32 \mathrm{~h}$ after feeding. It was estimated that at the end of the PETIS experiment 74.8
Fig. 2 Time course of $\mathrm{Cd}$ concentration in solution and amounts of $\mathrm{Cd}$ in roots and shoots of $S$. plumbizincicola fed with $\mathrm{NO}_{3}{ }^{-}$or $\mathrm{NH}_{4}{ }^{+}$. $R O I$ region of interest, ROIS $A$ and $B$ solution, ROIs $C$ and $D$ roots, ROIs $E$ and $F$ shoots. The curve fitted for $\mathrm{Cd}$ dynamics in solution is indicated (a)
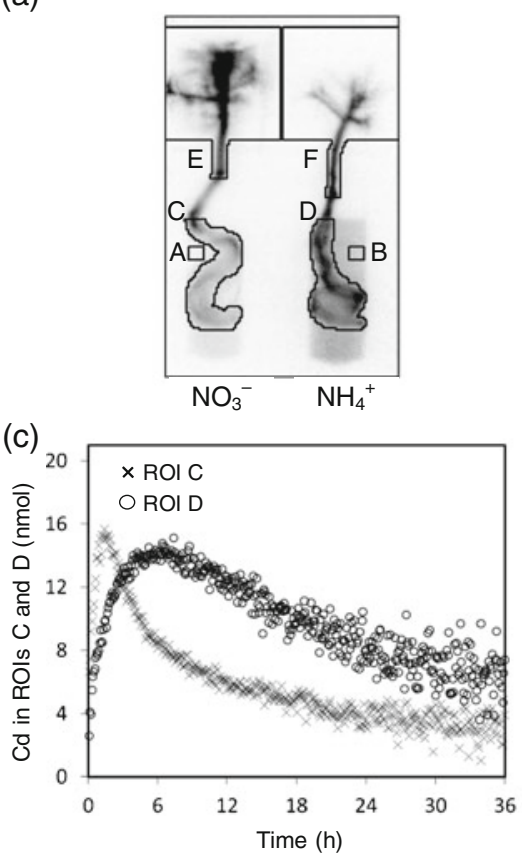

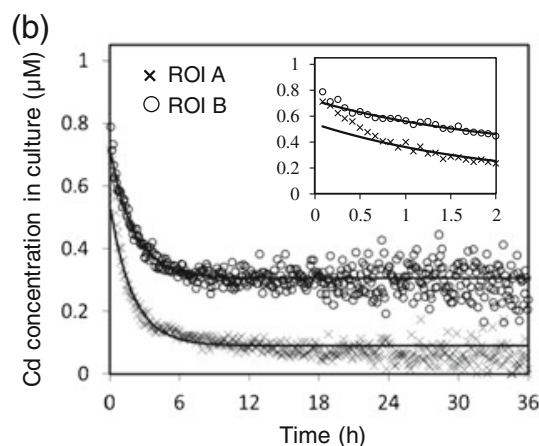

(d)

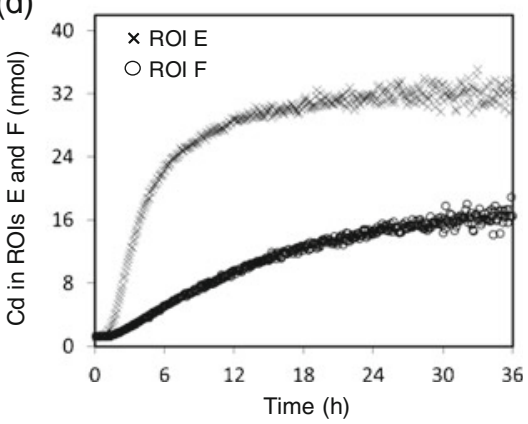


(a)

(b)
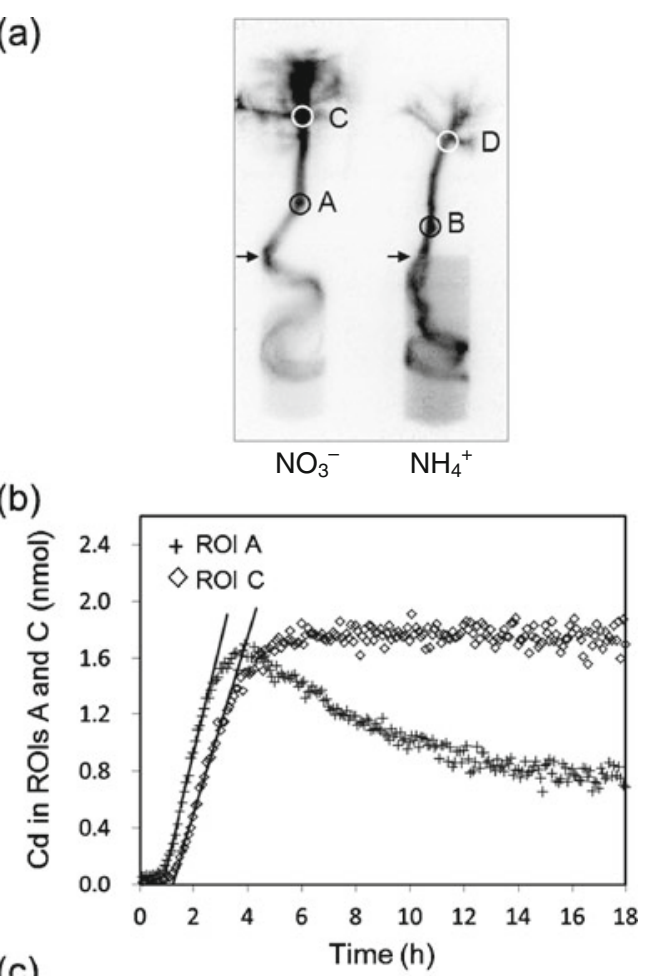

(c)

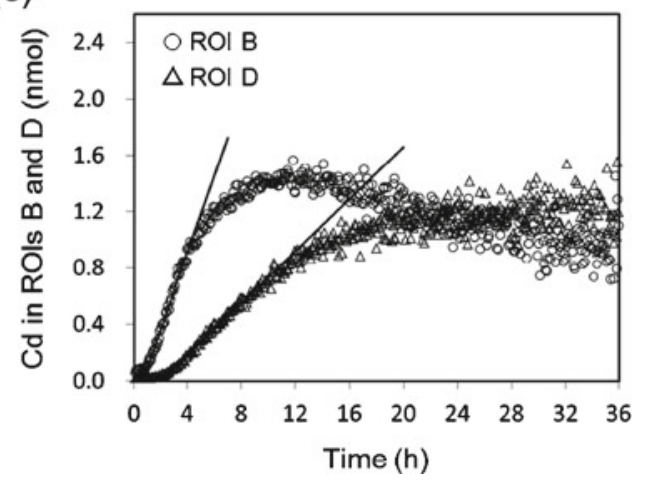

Fig. 3 Time course of amount of $\mathrm{Cd}$ in selected regions of $S$. plumbizincicola fed with $\mathrm{NO}_{3}{ }^{-}$or $\mathrm{NH}_{4}{ }^{+}$. $\mathrm{ROI}$ region of interest, $\mathrm{ROIs}$ $A$ and $B$ shoot base, ROIs $C$ and $D$ shoots; arrows indicate solution surface. Fitted lines are indicated to estimate the arrival times

and $51.4 \%$ of $\mathrm{Cd}$ absorbed by the roots was transported into the shoots in the $\mathrm{NO}_{3}{ }^{-}$- and $\mathrm{NH}_{4}{ }^{+}$-fed plants, respectively.

The timing and velocities of $\mathrm{Cd}$ transport from the nutrient solution to the shoots were analysed. ROIs A to D in Fig. 3a were for analysis of $\mathrm{Cd}$ transport velocity in roots and shoots shown in Fig. 3b, c. Initial slopes of the curves generated from the PETIS data were fitted to the lines and the $\mathrm{X}$ intercepts of the fitted lines were used as the arrival times of $\mathrm{Cd}$ at the respective ROIs (Fig. 3b, c). It was estimated that $\mathrm{Cd}$ arrived at the shoot base (ROIs $\mathrm{A}$ and B) at 0.83 and $0.65 \mathrm{~h}$ in $\mathrm{NO}_{3}{ }^{-}$- and $\mathrm{NH}_{4}{ }^{+}$-treated plants, respectively. Based on the distance from the solution surface to the shoot base, it was estimated that the local velocity of $\mathrm{Cd}$ transport in the roots (above the solution surface) was 3.30 and $2.20 \mathrm{~cm} \mathrm{~h}^{-1}$ in $\mathrm{NO}_{3}{ }^{-}$- and $\mathrm{NH}_{4}{ }^{+}$-treated plants, respectively. Moreover, $\mathrm{Cd}$ arrived at the selected shoot area ROIs C and D after 1.21 and $2.04 \mathrm{~h}$, respectively. Consequently, the local velocity of $\mathrm{Cd}$ transport in the shoots was estimated to be 10.10 and $2.70 \mathrm{~cm} \mathrm{~h}^{-1}$ in $\mathrm{NO}_{3}{ }^{-}$- and $\mathrm{NH}_{4}{ }^{+}$treated plants. Clearly, the transportation of $\mathrm{Cd}$ in xylem sap of roots and stem in $\mathrm{NO}_{3}{ }^{-}$-treated plant was much more rapid than in $\mathrm{NH}_{4}{ }^{+}$-treated plant. The rates of water uptake by the plants were monitored continuously and were shown to be highly constant during the experiment, with an average of 0.069 and $0.054 \mathrm{~g} \mathrm{~g}^{-1}$ plant $\mathrm{h}^{-1}$ (fitted from 0.5 to $36 \mathrm{~h}$ ) for $\mathrm{NO}_{3}{ }^{-}$and $\mathrm{NH}_{4}{ }^{+}$treatments (Fig. 4).

\section{Cd distribution by autoradiography}

After $36 \mathrm{~h}$ of PETIS experiments, the test plants were dissected and subjected to autoradiography of ${ }^{109} \mathrm{Cd}$. This provided the static distribution of $\mathrm{Cd}$ at individual leaf, stem and root, which is supplementary analysis above PETIS analysis at the whole shoot level (Fig. 5). Both test plants showed similar morphology with nine branches on the main stem. Strong accumulation of ${ }^{109} \mathrm{Cd}$ was observed in the main stems and roots of both $\mathrm{NO}_{3}{ }^{-}$- and $\mathrm{NH}_{4}{ }^{+}$-fed plants. Moreover, $\mathrm{Cd}$ accumulation in branches and young leaves (smaller leaves that linked to or near branch in Fig. 5) was higher than in mature leaves (larger leaves) of both plants. This indicates that $\mathrm{Cd}$ in the main stems was readily transported to the branch and young leaves other than mature leaves irrespective of $\mathrm{N}$ form. However, it was found that $\mathrm{Cd}$ accumulation in branch and young leaves of the $\mathrm{NO}_{3}{ }^{-}$-fed plant was stronger than in the $\mathrm{NH}_{4}{ }^{+}$-fed plant although the $\mathrm{Cd}$ signal in the main stems of these two plants appeared to be similar. This indicates that $\mathrm{Cd}$ transportation from the main stem to branches and young leaves in the $\mathrm{NO}_{3}{ }^{-}$-fed plant was promoted compared with the $\mathrm{NH}_{4}{ }^{+}$-fed plant.

\section{Cd concentrations in xylem sap}

Xylem sap was collected $2 \mathrm{~h}$ after $\mathrm{Cd}$ addition from $S$. plumbizincicola seedlings pre-fed with $1 \mathrm{mM} \mathrm{NO}_{3}{ }^{-}$or

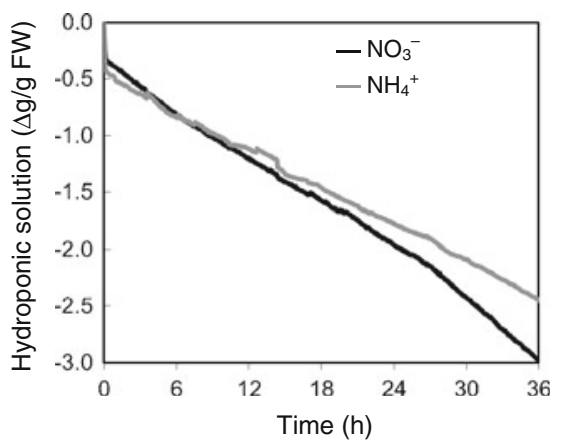

Fig. 4 Time course of water uptake by S. plumbizincicola fed with $\mathrm{NO}_{3}{ }^{-}$or $\mathrm{NH}_{4}{ }^{+}$ 
(a)

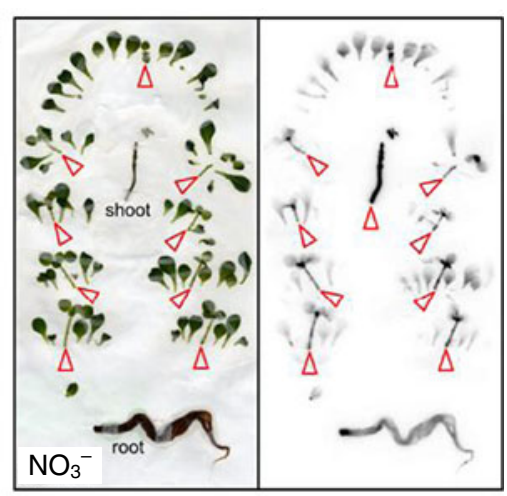

(b)

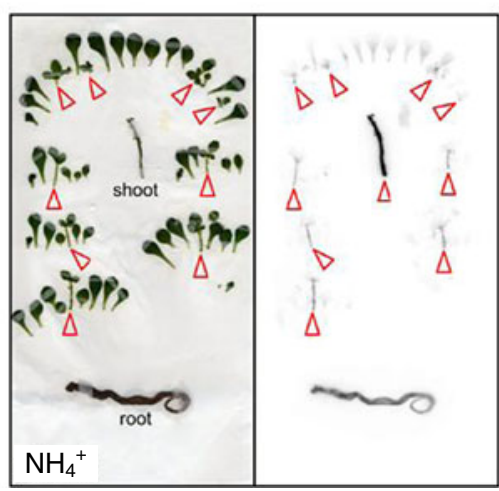

Fig. 5 Autoradiography of static ${ }^{109} \mathrm{Cd}$ in tissues of S. plumbizincicola pre-treated with $\mathrm{NO}_{3}{ }^{-}$or $\mathrm{NH}_{4}{ }^{+}$for 3 days and then supplied with $\mathrm{Cd}$ for $36 \mathrm{~h}$. Arrows indicate the main stem and branches

$\mathrm{NH}_{4}{ }^{+}$for 3 days (Table 1). The concentrations of $\mathrm{Cd}$ and other ions in the xylem sap were not significantly different between the two rates of $\mathrm{Cd}$ addition $(1$ and $30 \mu \mathrm{M})$. The $\mathrm{Cd}$ concentration in the xylem sap of $\mathrm{NO}_{3}{ }^{-}$pre-treated plants was 2.1 to 2.9 times higher than in $\mathrm{NH}_{4}{ }^{+}$pre-treated plants. The Cd concentration in the xylem sap of the $\mathrm{NO}_{3}^{-}$treatment was approximately 110 -fold higher than in the external solution $(1 \mu \mathrm{M})$ while in the $\mathrm{NH}_{4}{ }^{+}$treatment, it was approximately 50 -fold higher than in the external solution. Moreover, $\mathrm{Ca}$ and $\mathrm{K}$ concentrations in the xylem sap of $\mathrm{NO}_{3}{ }^{-}$pretreated plants were around 1.5 times higher than in $\mathrm{NH}_{4}^{+}$ pre-treated plants. However, Fe in the former was significantly lower than in the latter and $\mathrm{P}$ in the former was 1.5 times lower than in the latter. There was no significant difference in $\mathrm{Zn}$ or $\mathrm{Mg}$ concentrations in the xylem sap between $\mathrm{NO}_{3}{ }^{-}$and $\mathrm{NH}_{4}{ }^{+}$pre-treated plants.

Plant growth and $\mathrm{Cd}$ accumulation in long-term solution culture conditions

In the present hydroponic experiment $S$. plumbizincicola was supplied with $30 \mu \mathrm{M} \mathrm{Cd}$ and $1 \mathrm{mM} \mathrm{NO}_{3}{ }^{-}$or $\mathrm{NH}_{4}{ }^{+}$ (Table 2). There was no significant difference in dry biomass of shoots on the 6th day. However, there was 51.4 and $88.2 \%$ more shoot and root biomass, respectively, in the $\mathrm{NO}_{3}{ }^{-}$treatment compared with the $\mathrm{NH}_{4}{ }^{+}$treatment on the
21 st day. Shoot $\mathrm{Cd}$ concentrations were 1.88 and 2.63 times higher in the $\mathrm{NO}_{3}^{-}$than the $\mathrm{NH}_{4}^{+}$treatment on days 6 and 21 , but root $\mathrm{Cd}$ concentrations showed no difference. Consequently, shoot $\mathrm{Cd}$ accumulation was significantly promoted by $\mathrm{NO}_{3}{ }^{-}$treatment compared with $\mathrm{NH}_{4}{ }^{+}$because of the enhancement of both plant biomass and $\mathrm{Cd}$ transport to the shoots on the 21st day. It was observed that $\mathrm{Cd}$ accumulation in $\mathrm{NO}_{3}^{-}$-fed shoots reached $1.86 \mathrm{mg} \mathrm{pot}^{-1}$ after 21 days of culture, 4.23 times higher than in $\mathrm{NH}_{4}^{+}$-fed shoots.

\section{Discussion}

This is the first reported study to visualise Cd movement non-invasively in an intact $\mathrm{Cd}$ hyperaccumulator, $S$. plumbizincicola, using ${ }^{107} \mathrm{Cd}$ tracer and improved PETIS which enabled direct and simultaneous observation of the radiotracer-treated culture solution and plants (Fujimaki et al. 2010; Ishikawa et al. 2011). The imaging data were applied for quantitative analysis of the dynamics and kinetics of $\mathrm{Cd}$ uptake and transport in the whole plant supplied with two different inorganic $\mathrm{N}$ sources, $\mathrm{NO}_{3}{ }^{-}$and $\mathrm{NH}_{4}{ }^{+}$. Physiologically, the uptake of $\mathrm{NH}_{4}^{+}$will decrease the rhizosphere $\mathrm{pH}$, which results in an increase in metal bioavailability and consequently an increase in metal accumulation by plants. Considering this, the solution in the present experiment was buffered with $1 \mathrm{mM}$ MES-Tris to eliminate the effects of $\mathrm{pH}$ changes on $\mathrm{Cd}$ uptake. Moreover, concentrations of cation in solution, such as $\mathrm{Ca}^{2+}, \mathrm{K}^{+}$and $\mathrm{Mg}^{2+}$ were balanced between the $\mathrm{N}$ treatments to eliminate their competitive effects on Cd uptake ( $\mathrm{Lu}$ et al. 2008; Zhu et al. 2011). Therefore, the different $\mathrm{Cd}$ dynamics in this study were clearly atributable to the effects of the different forms of $\mathrm{N}$.

\section{Cd uptake by roots}

It is well known that $\mathrm{Cd}$ uptake by plant roots consists of apoplastic binding and symplastic uptake (Cataldo et al. 1983; Hart et al. 1998). Zhao et al. (2002) found that root apoplastic binding of $\mathrm{Cd}$ in the hyperaccumulator $N$. caerulescens reached a plateau after approximately $45 \mathrm{~min}$ and then symplastic uptake dominated the dynamics. In the present PETIS experiment, a drastic drop in the Cd absorption curve in solution was observed after the first few hours in both $\mathrm{N}$ treatments (Fig. 2b). A complex shape, which decreased more rapidly than first order reaction kinetics, appeared within the first $0.5 \mathrm{~h}$, especially in the $\mathrm{NO}_{3}{ }^{-}$ treatment (Fig. 2b). A similar phenomenon was observed in previous studies of $\mathrm{Cd}$ uptake dynamics in rice (Fujimaki et al. 2010; Ishikawa et al. 2011). This may be explained in terms of the complicated combination of both apoplastic binding and symplastic uptake of $\mathrm{Cd}$ by the roots. After 
Table 1 Elemental concentrations in the xylem sap of Sedum plumbizincicola pre-treated with $1 \mathrm{mM} \mathrm{NO}_{3}^{-}$or $\mathrm{NH}_{4}{ }^{+}$for 3 days and then supplied with different concentrations of $\mathrm{Cd}$ for $2 \mathrm{~h}$

\begin{tabular}{lcclllll}
\hline Treatment & $\mathrm{Cd}(\mu \mathrm{M})$ & $\mathrm{Ca}(\mathrm{mM})$ & $\mathrm{K}(\mathrm{mM})$ & $\mathrm{Mg}(\mathrm{mM})$ & $\mathrm{Fe}(\mu \mathrm{M})$ & $\mathrm{Zn}(\mu \mathrm{M})$ & $\mathrm{P}(\mathrm{mM})$ \\
\hline $1 \mathrm{mM} \mathrm{NO}_{3}{ }^{-}+1 \mu \mathrm{M} \mathrm{Cd}$ & $111 \pm 6 \mathrm{a}$ & $5.47 \pm 0.52 \mathrm{a}$ & $4.07 \pm 0.45 \mathrm{a}$ & $1.08 \pm 0.07 \mathrm{a}$ & $0.90 \pm 0.58 \mathrm{~b}$ & $89.9 \pm 9.9 \mathrm{a}$ & $0.77 \pm 0.15 \mathrm{~b}$ \\
$1 \mathrm{mM} \mathrm{NH}_{4}{ }^{+}+1 \mu \mathrm{M} \mathrm{Cd}$ & $38.0 \pm 26.0 \mathrm{~b}$ & $3.80 \pm 0.26 \mathrm{c}$ & $2.64 \pm 0.28 \mathrm{~b}$ & $1.10 \pm 0.15 \mathrm{a}$ & $26.1 \pm 8.0 \mathrm{a}$ & $86.2 \pm 23.6 \mathrm{a}$ & $1.18 \pm 0.15 \mathrm{a}$ \\
$1 \mathrm{mM} \mathrm{NO}_{3}{ }^{-}+30 \mu \mathrm{M} \mathrm{Cd}$ & $107 \pm 2 \mathrm{a}$ & $4.49 \pm 0.41 \mathrm{~b}$ & $4.52 \pm 0.35 \mathrm{a}$ & $1.03 \pm 0.08 \mathrm{a}$ & $1.55 \pm 1.13 \mathrm{~b}$ & $89.2 \pm 40.2 \mathrm{a}$ & $0.77 \pm 0.13 \mathrm{~b}$ \\
$1 \mathrm{mM} \mathrm{NH}_{4}{ }^{+}+30 \mu \mathrm{M} \mathrm{Cd}$ & $50.0 \pm 3.0 \mathrm{~b}$ & $3.30 \pm 0.36 \mathrm{c}$ & $2.77 \pm 0.37 \mathrm{~b}$ & $0.91 \pm 0.15 \mathrm{a}$ & $22.2 \pm 5.0 \mathrm{a}$ & $98.2 \pm 25.3 \mathrm{a}$ & $1.15 \pm 0.41 \mathrm{a}$ \\
\hline
\end{tabular}

Values are means $\pm \mathrm{SD}(n=4)$; different letters in the same column indicate significant differences based on one-way ANOVA followed by LSD test $(P<0.05)$

$0.5 \mathrm{~h}$, the dynamics of Cd uptake by the roots in both $\mathrm{N}$ treatments were fitted well by the first order reaction kinetics (Fig. 2b; Eq. 1), indicating that transporter-mediated symplastic $\mathrm{Cd}$ uptake and transportation dominated the dynamics.

The time course of $\mathrm{Cd}$ dynamics in both solution and roots (Fig. 2b, c) indicates that the $\mathrm{Cd}$ absorption rate was always higher in the $\mathrm{NO}_{3}{ }^{-}$treatment than the $\mathrm{NH}_{4}{ }^{+}$treatment. The higher $\mathrm{Cd}$ absorption rate by the roots of $\mathrm{NO}_{3}{ }^{-}$ might be attributed to $\mathrm{NO}_{3}{ }^{-}$-enhanced up-regulation of $\mathrm{Cd}$ transporters involved in symplastic uptake and transportation of $\mathrm{Cd}$ in the roots. It is known that in addition to its nutrient function $\mathrm{NO}_{3}{ }^{-}$also acts as a signal molecule that controls many aspects of plant metabolism and development (Crawford 1995; Stitt 1999; Krouk et al. 2010). It is estimated that $\mathrm{NO}_{3}{ }^{-}$responsive genes may account for up to $10 \%$ of the transcriptome (Krouk et al. 2010). Luo et al. (2012) reported that compared with $\mathrm{NH}_{4}{ }^{+}, \mathrm{NO}_{3}{ }^{-}$application directly enhances $\mathrm{Cd}$ uptake of tomato, which they attributed to the up-regulation of the Fe uptake systems in the roots. In the present study, considering the depressed $\mathrm{Fe}$ but elevated $\mathrm{K}$ and $\mathrm{Ca}$ concentrations in the xylem sap of the $\mathrm{NO}_{3}{ }^{-}$ treatment (Table 1), it appears that $\mathrm{Cd}$ is taken up by the roots instead of Fe. Moreover, it would be reasonable that $\mathrm{NO}_{3}{ }^{-}$might up-regulate the expression of $\mathrm{K}$ transporters or $\mathrm{Ca}$ channels which can also be involved in low-affinity $\mathrm{Cd}$ uptake and translocation in the roots. Furthermore, $\mathrm{NO}_{3}{ }^{-}$ transport across the plasma membrane results in the membrane potential being temporarily depolarised and then being hyperpolarised (McClure et al. 1990; Miller et al. 2001) and this may enhance the membrane transport of cations. In contrast, uptake of $\mathrm{NH}_{4}{ }^{+}$depolarises the membrane potential and thus inhibits cation uptake (Crawford and Glass 1998). On the other hand, it was also observed that a higher concentration of $\mathrm{Cd}(0.290 \mu \mathrm{M})$ in the culture solution still remained unabsorbed after the plateau in the $\mathrm{NH}_{4}{ }^{+}$treatments, while it was depleted to a much lower level $(0.056 \mu \mathrm{M})$ in the $\mathrm{NO}_{3}{ }^{-}$treatments (Fig. 2b). It seems that, compared with $\mathrm{NO}_{3}{ }^{-}, \mathrm{NH}_{4}{ }^{+}$competed with $\mathrm{Cd}$ uptake by the root. Nevertheless, another possible explanation is that $\mathrm{NO}_{3}{ }^{-}$induced the expression of some high-affinity $\mathrm{Cd}$ transporters in the roots of S. plumbizincicola which operated efficiently at a low external $\mathrm{Cd}$ concentration.

Cd translocation from root to shoot

In general, the root-to-shoot translocation of heavy metals is theoretically dependent on the following processes: (1) symplastic uptake by the roots, (2) root retention, (3) xylem loading, and (4) xylem unloading and uptake by leaf cells. Low vacuolar sequestration in roots and rapid xylem loading are critical characters for hyperaccumulator plants (Baker et al. 1994; Lasat et al. 1996, 1998; Zhao et al. 2006). In the present study, the Cd dynamics in the root reflect the combination of $\mathrm{Cd}$ uptake from the solution and the transfer from root to shoot, including retention within vacuoles and

Table 2 Dry weights of shoots and roots, Cd concentration and accumulation of Sedum plumbizincicola hydroponically fed with $30 \mu \mathrm{M}$ Cd and $1 \mathrm{mM} \mathrm{NO}_{3}^{-}$or $\mathrm{NH}_{4}^{+}$for 6 or 21 days

\begin{tabular}{|c|c|c|c|c|c|c|c|}
\hline \multirow[t]{2}{*}{ Plant part } & \multirow[t]{2}{*}{ Nitrogen form } & \multicolumn{2}{|c|}{ Dry weight $\left(\mathrm{mg} \operatorname{pot}^{-1}\right)$} & \multicolumn{2}{|c|}{$\mathrm{Cd}$ concentration $\left(\mathrm{mg} \mathrm{kg}^{-1}\right)$} & \multicolumn{2}{|c|}{ Plant $\mathrm{Cd}$ accumulation $\left(\mathrm{mg} \operatorname{pot}^{-1}\right)$} \\
\hline & & 6 days & 21 days & 6 days & 21 days & 6 days & 21 days \\
\hline \multirow[t]{2}{*}{ Shoots } & $\mathrm{NO}_{3}^{-}$ & $237 \pm 32 \mathrm{a}$ & $504 \pm 78$ a & $1799 \pm 626 \mathrm{a}$ & $3262 \pm 852$ a & $0.41 \pm 0.11 \mathrm{a}$ & $1.86 \pm 0.43 \mathrm{a}$ \\
\hline & $\mathrm{NH}_{4}^{+}$ & $208 \pm 33$ a & $333 \pm 58 \mathrm{~b}$ & $959 \pm 187$ a & $1241 \pm 281 \mathrm{~b}$ & $0.20 \pm 0.02 \mathrm{~b}$ & $0.44 \pm 0.08 \mathrm{~b}$ \\
\hline \multirow[t]{2}{*}{ Roots } & $\mathrm{NO}_{3}^{-}$ & $29 \pm 2 \mathrm{a}$ & $64 \pm 17$ a & $2469 \pm 94 \mathrm{a}$ & $3511 \pm 517$ a & $0.07 \pm 0.01 \mathrm{a}$ & $0.22 \pm 0.05 \mathrm{a}$ \\
\hline & $\mathrm{NH}_{4}^{+}$ & $19 \pm 3 b$ & $34 \pm 6 b$ & $2524 \pm 299 \mathrm{a}$ & $2941 \pm 537$ a & $0.05 \pm 0.01 \mathrm{a}$ & $0.10 \pm 0.01 \mathrm{~b}$ \\
\hline
\end{tabular}

Values are means $\pm \mathrm{SD}(n=4)$. For each trait, means in columns followed by different letters indicate significant differences from each other according to independent-sample $t$ test $(P<0.05)$ 
xylem loading (Fig. 2c). The drastic drop after $1.4 \mathrm{~h}$ in the $\mathrm{NO}_{3}{ }^{-}$-fed plant may be attributed to the rapid depletion of the $\mathrm{Cd}$ supply from solution to root, low vacuolar sequestration and vigorous xylem loading. In contrast, the gentle saturation and slow decline curves in the $\mathrm{NH}_{4}{ }^{+}$-treated plant indicate stronger retention within vacuoles and relatively low xylem loading. Generally, compared with $\mathrm{NO}_{3}{ }^{-}, \mathrm{NH}_{4}{ }^{+}$ is assimilated into some amino acids and consequently some classes of proteins in roots, which might facilitate the vacuolar sequestration of $\mathrm{Cd}$ in the roots but decrease xylem loading and translocation to the shoots (Yang et al. 2006). Moreover, xylem sap analysis revealed that the $\mathrm{Cd}$ concentration in $\mathrm{NO}_{3}^{-}$and $\mathrm{NH}_{4}{ }^{+}$treatments was around 110- and 50 -fold higher than that in the external solution $(1 \mu \mathrm{M})$, respectively (Table 1 ). Though there was a risk that the xylem sap sample in micro tubes was concentrated as water evaporated during sap collection, it can be concluded that xylem loading of $\mathrm{Cd}$ was more efficient in the $\mathrm{NO}_{3}{ }^{-}$-fed plant than in the $\mathrm{NH}_{4}{ }^{+}$-fed plant. This is also consistent with the Cd dynamics in the shoots (Fig. 2d). Recently, numerous studies have demonstrated that $\mathrm{P}_{1 \mathrm{~B}}$-type heavy metal ATPase, HMA4, localised at the plasma membranes and expressed predominantly in the root vascular tissues, likely plays an important role in the xylem loading of $\mathrm{Cd}$ and $\mathrm{Zn}$ in the hyperaccumulators $N$. caerulescens and Arabidopsis halleri (Becher et al. 2004; Papoyan and Kochian 2004; Talke et al. 2006). Thus, compared with $\mathrm{NH}_{4}{ }^{+}, \mathrm{NO}_{3}{ }^{-}$may also induce the up-regulated expression of $\mathrm{Cd}$ transporters involved in Cd xylem loading in addition to Cd uptake in $S$. plumbizincicola.

The present study shows that the local velocity of $\mathrm{Cd}$ transport was approximately 1.5 - and 3.7 -fold higher in the roots and shoots of $\mathrm{NO}_{3}^{-}$-fed plants than $\mathrm{NH}_{4}^{+}$-fed plants, respectively (Fig. 3). Moreover, at the end of the PETIS experiment a larger proportion of the $\mathrm{Cd}$ absorbed by the roots was transported into the shoots in the $\mathrm{NO}_{3}{ }^{-}$-fed plants $(74.8 \%)$ than the $\mathrm{NH}_{4}{ }^{+}$-fed plants $(51.4 \%)$. Autoradiography of ${ }^{109} \mathrm{Cd}$ after PETIS also reveals that $\mathrm{Cd}$ transportation from the main stem to branches and young leaves in $\mathrm{NO}_{3}{ }^{-}$-fed plants was promoted compared with $\mathrm{NH}_{4}{ }^{+}$-fed plants (Fig. 5). Generally, root-to-shoot translocation of $\mathrm{Cd}$ occurs via the xylem and is driven by transpiration from the leaves. In the present study, the rates of water uptake by $\mathrm{NO}_{3}{ }^{-}$-fed plants $\left(0.069 \mathrm{~g} \mathrm{~g}^{-1}\right.$ plant $\left.\mathrm{h}^{-1}\right)$ were slightly higher $(1.3$-fold $)$ than $\mathrm{NH}_{4}^{+}$-treated plants $\left(0.054 \mathrm{~g} \mathrm{~g}^{-1}\right.$ plant $\left.\mathrm{h}^{-1}\right)$ (Fig. 4). However, the differences in water uptake cannot fully explain the differences in local velocity of $\mathrm{Cd}$ transport (3.7-fold) and the differences in $\mathrm{Cd}$ distribution between these two $\mathrm{N}$ treatments. Comparatively, it is suggested that unlike $\mathrm{NH}_{4}^{+}$which is mainly assimilated or stored in the roots, $\mathrm{NO}_{3}{ }^{-}$is translocated as a hydrated anion in the xylem where cationic charges are required for charge balance (Monsant et al. 2010). Meanwhile, $\mathrm{NO}_{3}{ }^{-}$fertiliser enhanced the accumulation of organic anions, such as glutamate, malate and oxalate in the shoots and this was accompanied by an increase in the concentrations of cations $\left(\mathrm{K}^{+}, \mathrm{Ca}^{2+}, \mathrm{Mg}^{2+}\right.$ and $\mathrm{Na}^{+}$) (Arnozis and Findenegg 1986; Turan and Sevimli 2005). This is consistent with our results showing that concentrations of the cations $\mathrm{Ca}$ and $\mathrm{K}$ in the xylem sap increased but the anion $\mathrm{P}$ was inhibited in the $\mathrm{NO}_{3}{ }^{-}$treatment compared with the $\mathrm{NH}_{4}{ }^{+}$treatment (Table 1). Moreover, it has been demonstrated that $\mathrm{Cd}$ in the xylem sap of the hyperaccumulator $A$. halleri was mainly in aqueous free ionic form and with little Cd-citrate complexation (Ueno et al. 2008). Moreover, stimulated production of valine and other responsive amino acids may be involved in $\mathrm{Zn}$ unloading into leaf cells of the hyperaccumulator S. alfredii (Yang et al. 2006). Therefore, the charge balance from the anion $\mathrm{NO}_{3}{ }^{-}$ and organic acids in the xylem sap may be responsible for the higher transport velocity of $\mathrm{Cd}$. Meanwhile some organic acids may facilitate $\mathrm{Cd}$ unloading into leaf cells in $\mathrm{NO}_{3}{ }^{-}$treated plants compared with $\mathrm{NH}_{4}{ }^{+}$-treated plants. These effects together enhance $\mathrm{Cd}$ transportation from root to shoot in S. plumbizincicola. Further physiological and molecular research is required to confirm these hypotheses.

\section{Plant biomass and $\mathrm{Cd}$ accumulation}

In the present long-term hydroponics experiments, plant growth was also significantly promoted by $\mathrm{NO}_{3}{ }^{-}$nutrition compared with $\mathrm{NH}_{4}{ }^{+}$. As a result, $\mathrm{Cd}$ hyperaccumulation in $S$. plumbizincicola was largely enhanced by $\mathrm{NO}_{3}{ }^{-}$supplementation rather than $\mathrm{NH}_{4}^{+}$(Table 2). This is consistent with previous studies showing that $\mathrm{NO}_{3}{ }^{-}$fertilisation led to both higher biomass production and higher $\mathrm{Cd}$ and $\mathrm{Zn}$ extraction than $\mathrm{NH}_{4}{ }^{+}$in N. caerulescens (Schwartz et al. 2003; Monsant et al. 2008, 2010, 2011; Xie et al. 2009), camomile (Kovacik et al. 2011) and tomato (Luo et al. 2012). The stimulated uptake of nutrient elements such as $\mathrm{Ca}$ and $\mathrm{K}$ may be partly responsible for the stimulation of plant growth. The ameliorated plant metabolism and development process may in turn improve $\mathrm{Cd}$ tolerance and detoxification resulting in a further increase in Cd accumulation in S. plumbizincicola. We suggest that $S$. plumbizincicola is usually grown in dry fields where $\mathrm{N}$ tends to be predominantly in the $\mathrm{NO}_{3}{ }^{-}$form. This adaptability thus makes the hyperaccumulator prefer $\mathrm{NO}_{3}{ }^{-}$ nutrition to $\mathrm{NH}_{4}^{+}$.

\section{Conclusions}

This is the first report of successful visualisation and quantification of Cd uptake and root-to-shoot translocation in intact plants of the hyperaccumulator species $S$. plumbizincicola supplied with different forms of inorganic $\mathrm{N}$ using PETIS, a real-time imaging method. The results provide clear physiological evidence that compared with $\mathrm{NH}_{4}{ }^{+}, \mathrm{NO}_{3}{ }^{-}$promoted 
plant growth and the major steps in the transport route of $\mathrm{Cd}$ from solution to shoots including its uptake by roots, xylem loading, root-to-shoot translocation in the xylem, and unloading to leaves. As a result, $\mathrm{Cd}$ accumulation in the shoots was largely enhanced. Thus, in the present hydroponic conditions $\mathrm{NO}_{3}{ }^{-}$fertilisation rather than $\mathrm{NH}_{4}{ }^{+}$is the preferred choice for Cd phytoextraction by S. plumbizincicola but further research is required to investigate the effects in soil conditions where the chemical and physiological processes involved will be more complicated than in nutrient solution conditions.

Acknowledgements This research was supported by the National Natural Science Foundation of China (Projects 40930739, 41201300 and 41230858), by a grant from the Strategic International Cooperative Program, Japanese Science and Technology Agency (JST) and in part by the Japanese Society for the Promotion of Science (Grant-in-Aid for Scientific Research No. 23380155). We thank Mr. H. Suto (Tokyo Nuclear Services Co. Ltd.) and Dr. S. Ishii (Japanese Atomic Energy Agency) for the technical assistance in ${ }^{107} \mathrm{Cd}$ production, and Prof C. X. Tang (La Trobe University, Australia) for helps on experimental design and paper improvement.

\section{References}

Arnozis PA, Findenegg GR (1986) Electrical charge balance in the xylem sap of beet and Sorghum plants grown with either $\mathrm{NO}_{3}$ or $\mathrm{NH}_{4}$ nitrogen. J Plant Physiol 125:441-449

Baker AJM, Reeves RD, Hajar ASM (1994) Heavy metal accumulation and tolerance in British populations of the metallophyte Thlaspi caerulescens J. and C. Presl (Brassicaceae). New Phytol 127:61-68

Becher M, Talke IN, Krall L, Kramer U (2004) Cross-species microarray transcript profiling reveals high constitutive expression of metal homeostasis genes in shoots of the zinc hyperaccumulator Arabidopsis halleri. Plant J 37:251-268

Cataldo DA, Garland TR, Wildung RE (1983) Cadmium uptake kinetics in intact soybean plants. Plant Physiol 73:844-848

Cosio C, DeSantis L, Frey B, Diallo S, Keller C (2005) Distribution of cadmium in leaves of Thlaspi caerulescens. J Exp Bot 56:765-775

Courbot M, Willems G, Motte P, Arvidsson S, Roosens N, SaumitouLaprade P, Verbruggen N (2007) A major quantitative trait locus for cadmium tolerance in Arabidopsis halleri colocalizes with HMA4, a gene encoding a heavy metal ATPase. Plant Physiol 144:1052-1065

Crawford NM (1995) Nitrate- nutrient and signal for plant-growth. Plant Cell 7:859-868

Crawford NM, Glass ADM (1998) Molecular and physiological aspects of nitrate uptake in plants. Trends Plant Sci 3:389-395

Fujimaki S, Suzui N, Ishioka NS, Kawachi N, Ito S, Chino M, Nakamura S (2010) Tracing cadmium from culture to spikelet: noninvasive imaging and quantitative characterization of absorption, transport, and accumulation of cadmium in an intact rice plant. Plant Physiol 152:1796-1806

Hart JJ, Welch RM, Norvell WA, Sullivan LA, Kochian LV (1998) Characterization of cadmium binding, uptake, and translocation in intact seedlings of bread and durum wheat cultivars. Plant Physiol 116:1413-1420

Ishikawa $\mathrm{S}$, Suzui $\mathrm{N}$, Ito-Tanabata $\mathrm{S}$, Ishii $\mathrm{S}$, Igura $\mathrm{M}$, Abe $\mathrm{T}$, Kuramata M, Kawachi N, Fujimaki S (2011) Real-time imaging and analysis of differences in cadmium dynamics in rice cultivars
(Oryza sativa) using positron-emitting ${ }^{107} \mathrm{Cd}$ tracer. BMC Plant Biol 11:172

Jiang JP, Wu LH, Li N, Luo YM, Liu L, Zhao QG, Zhang L, Christie P (2010) Effects of multiple heavy metal contamination and repeated phytoextraction by Sedum plumbizincicola on soil microbial properties. Eur J Soil Biol 46:18-26

Kovacik J, Klejdus B, Stork F, Hedbavny J (2011) Nitrate deficiency reduces cadmium and nickel accumulation in chamomile plants. $\mathrm{J}$ Agr Food Chem 59:5139-5149

Krouk G, Crawford NM, Coruzzi GM, Tsay YF (2010) Nitrate signaling: adaptation to fluctuating environments. Curr Opin Plant Biol 13:266-273

Kupper H, Mijovilovich A, Meyer-Klaucke W, Kroneck PMH (2004) Tissue- and age-dependent differences in the complexation of cadmium and zinc in the cadmium/zinc hyperaccumulator Thlaspi caerulescens (Ganges ecotype) revealed by X-ray absorption spectroscopy. Plant Physiol 134:748-757

Lasat MM, Baker AJM, Kochian LV (1996) Physiological characterization of root $\mathrm{Zn}^{2+}$ absorption and translocation to shoots in $\mathrm{Zn}$ hyperaccumulator and nonaccumulator species of Thlaspi. Plant Physiol 112:1715-1722

Lasat MM, Baker AJM, Kochian LV (1998) Altered Zn compartmentation in the root symplasm and stimulated $\mathrm{Zn}$ absorption into the leaf as mechanisms involved in $\mathrm{Zn}$ hyperaccumulation in Thlaspi caerulescens. Plant Physiol 118:875-883

Liu L, Wu LH, Li N, Cui LQ, Li Z, Jiang JP, Jiang YG, Qiu XY, Luo YM (2009) Effect of planting densities on yields and zinc and cadmium uptake by Sedum plumbizincicola. Environ Sci 30:3422-3426 (in Chinese with English abstract)

Liu L, Wu LH, Li N, Luo YM, Li SL, Li Z, Han CL, Jiang YG, Christie P (2011) Rhizosphere concentrations of zinc and cadmium in a metal contaminated soil after repeated phytoextraction by Sedum plumbizincicola. Int J Phytoremediat 13:750-764

Lombi E, Tearall KL, Howarth JR, Zhao FJ, Hawkesford MJ, McGrath SP (2002) Influence of iron status on cadmium and zinc uptake by different ecotypes of the hyperaccumulator Thlaspi caerulescens. Plant Physiol 128:1359-1367

Lu LL, Tian SK, Yang XE, Wang XC, Brown P, Li TQ, He ZL (2008) Enhanced root-to-shoot translocation of cadmium in the hyperaccumulating ecotype of Sedum alfredii. J Exp Bot 59:3203-3213

Luo BF, Du ST, Lu KX, Liu WJ, Lin XY, Jin CW (2012) Iron uptake system mediates nitrate-facilitated cadmium accumulation in tomato (Solanum lycopersicum) plants. J Exp Bot 63:3127-3136

Ma JF, Ueno D, Zhao FJ, McGrath SP (2005) Subcellular localisation of $\mathrm{Cd}$ and $\mathrm{Zn}$ in the leaves of a Cd-hyperaccumulating ecotype of Thlaspi caerulescens. Planta 220:731-736

McClure PR, Kochian LV, Spanswick RM, Shaff JE (1990) Evidence for cotransport of nitrate and protons in maize roots 1. Effects of nitrate on the membrane-potential. Plant Physiol 93:281-289

McGrath SP, Lombi E, Gray CW, Caille N, Dunham SJ, Zhao FJ (2006) Field evaluation of $\mathrm{Cd}$ and $\mathrm{Zn}$ phytoextraction potential by the hyperaccumulators Thlaspi caerulescens and Arabidopsis halleri. Environ Pollut 141:115-125

Miller AJ, Cookson SJ, Smith SJ, Wells DM (2001) The use of microelectrodes to investigate compartmentation and the transport of metabolized inorganic ions in plants. J Exp Bot 52:541-549

Monsant AC, Tang C, Baker AJM (2008) The effect of nitrogen form on rhizosphere soil $\mathrm{pH}$ and zinc phytoextraction by Thlaspi caerulescens. Chemosphere 73:635-642

Monsant AC, Wang YD, Tang CX (2010) Nitrate nutrition enhances zinc hyperaccumulation in Noccaea caerulescens (Prayon). Plant Soil 336:391-404

Monsant AC, Kappen P, Wang YD, Pigram PJ, Baker AJM, Tang CX (2011) In vivo speciation of zinc in Noccaea caerulescens in response to nitrogen form and zinc exposure. Plant Soil 348:167-183 
Papoyan A, Kochian LV (2004) Identification of Thlaspi caerulescens genes that may be involved in heavy metal hyperaccumulation and tolerance. Characterization of a novel heavy metal transporting ATPase. Plant Physiol 136:3814-3823

Sarathchandra SU (1978) Nitrification activities and changes in populations of nitrifying bacteria in soil perfused at 2 different H-ion concentrations. Plant Soil 50:99-111

Schwartz C, Echevarria G, Morel JL (2003) Phytoextraction of cadmium with Thlaspi caerulescens. Plant Soil 249:27-35

Stitt M (1999) Nitrate regulation of metabolism and growth. Curr Opin Plant Biol 2:178-186

Suzuki M, Tsukamoto T, Inoue H, Watanabe S, Matsuhashi S, Takahashi M, Nakanishi H, Mori S, Nishizawa NK (2008) Deoxymugineic acid increases $\mathrm{Zn}$ translocation in $\mathrm{Zn}$-deficient rice plants. Plant Mol Biol 66:609-617

Talke IN, Hanikenne M, Kramer U (2006) Zinc-dependent global transcriptional control, transcriptional deregulation, and higher gene copy number for genes in metal homeostasis of the hyperaccumulator Arabidopsis halleri. Plant Physiol 142:148-167

Tsukamoto T, Nakanishi H, Kiyomiya S, Watanabe S, Matsuhashi S, Nishizawa NK, Mori S (2006) ${ }^{52} \mathrm{Mn}$ translocation in barley monitored using a positron-emitting tracer imaging system. Soil Sci Plant Nutr 52:717-725

Tsukamoto T, Nakanishi H, Uchida H, Watanabe S, Matsuhashi S, Mori S, Nishizawa NK (2009) ${ }^{52} \mathrm{Fe}$ translocation in barley as monitored by a positron-emitting tracer imaging system (PETIS): evidence for the direct translocation of Fe from roots to young leaves via phloem. Plant Cell Physiol 50:48-57

Turan M, Sevimli F (2005) Influence of different nitrogen sources and levels on ion content of cabbage (Brassica oleracea var. capitate). New Zeal J Crop Hort 33:241-249

Ueno D, Ma JF, Iwashita T, Zhao FJ, McGrath SP (2005) Identification of the form of $\mathrm{Cd}$ in the leaves of a superior Cd-accumulating ecotype of Thlaspi caerulescens using ${ }^{113} \mathrm{Cd}-\mathrm{NMR}$. Planta 221:928-936

Ueno D, Iwashita T, Zhao FJ, Ma JF (2008) Characterization of Cd translocation and identification of the $\mathrm{Cd}$ form in xylem sap of the $\mathrm{Cd}-$ hyperaccumulator Arabidopsis halleri. Plant Cell Physiol 49:540-548

Uraguchi S, Mori S, Kuramata M, Kawasaki A, Arao T, Ishikawa S (2009) Root-to-shoot Cd translocation via the xylem is the major process determining shoot and grain cadmium accumulation in rice. J Exp Bot 60:2677-2688

Wu LH, Zhou SB, Bi D, Guo XH, Qin WH, Wang H, Wang GJ, Luo YM (2006) Sedum plumbizincicola, a new species of the Crassulaceae from Zhejiang. Soils 38:632-633 (in Chinese with English abstract)
Wu LH, Li N, Bi D, Luo YM (2007) Zn and Cd hyperaccumulator in Sedum plumbizincicola under different soil contamination levels and intercropping systems. In: Zhu YG, Lepp N, Naidu R (eds) Biogeochemisry of trace elements: environmental protection, remediation and human health. Tsinghua University Press, Beijing, pp 934-935

Wu LH, Li N, Luo YM (2008) Phytoextraction of heavy metal contaminated soil by Sedum plumbizincicola under different agronomic strategies. In: Proc 5th Int Phytotech Conf, Nanjing, China, pp. $49-50$

Wu LH, Li Z, Akahane I, Liu L, Han CL, Makino T, Luo YM, Christie $\mathrm{P}$ (2012) Effects of organic amendments on $\mathrm{Cd}, \mathrm{Zn}$ and $\mathrm{Cu}$ bioavailability in soil with repeated phytoremediation by Sedum plumbizincicola. Int J Phytoremediat 14:1024-1038

Wu LH, Liu YJ, Zhou SB, Guo FG, Bi D, Guo XH, Baker AJM, Smith JAC, Luo YM (2013a) Sedum plumbizincicola X.H. Guo et S.B. Zhou ex L.H. Wu (Crassulaceae): a new species from Zhejiang Province, China. Plant Syst Evol 299(3):487-498

Wu LH, Zhong DX, Du YZ, Lu SY, Fu DQ, Li Z, Li XD, Chi Y, Luo YM, Yan JH (2013b) Emission and control characteristics for incineration of Sedum plumbizincicola biomass in a laboratoryscale entrained flow tube furnace. Int J Phytoremediat 15:219231

Xie HL, Jiang RF, Zhang FS, McGrath SP, Zhao FJ (2009) Effect of nitrogen form on the rhizosphere dynamics and uptake of cadmium and zinc by the hyperaccumulator Thlaspi caerulescens. Plant Soil 318:205-215

Yang XE, Li TQ, Long XX, Xiong YH, He ZL, Stoffella PJ (2006) Dynamics of zinc uptake and accumulation in the hyperaccumulating and non-hyperaccumulating ecotypes of Sedum alfredii Hance. Plant Soil 284:109-119

Zaccheo P, Crippa L, Pasta VD (2006) Ammonium nutrition as a strategy for cadmium mobilisation in the rhizosphere of sunflower. Plant Soil 283:43-56

Zhao FJ, Hamon RE, Lombi E, McLaughlin MJ, McGrath SP (2002) Characteristics of cadmium uptake in two contrasting ecotypes of the hyperaccumulator Thlaspi caerulescens. J Exp Bot 53:535543

Zhao FJ, Jiang RF, Dunham SJ, McGrath SP (2006) Cadmium uptake, translocation and tolerance in the hyperaccumulator Arabidopsis halleri. New Phytol 172:646-654

Zhu E, Liu D, Li JG, Li TQ, Yang XE, He ZL, Stoffella PJ (2011) Effect of nitrogen fertilizer on growth and cadmium accumulation in Sedum alfredii Hance. J Plant Nutr 34:115126 